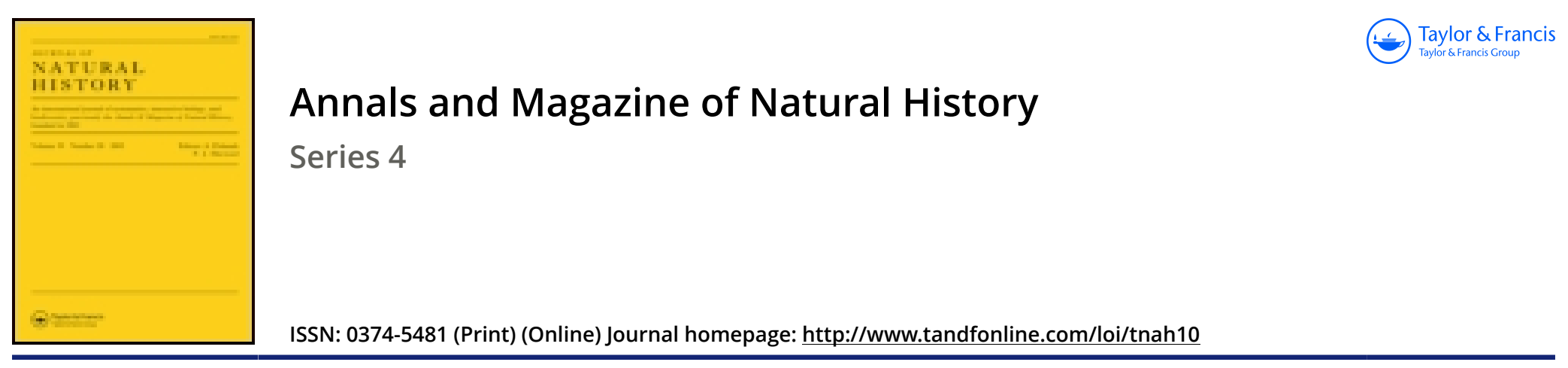

\title{
VII.-Description of a new species of skink
}

\section{A.W.E. O'Shaughnessy}

To cite this article: A.W.E. O'Shaughnessy (1874) VII.-Description of a new species of skink , Annals and Magazine of Natural History, 14:79, 35-35, DOI: 10.1080/00222937408680917

To link to this article: http://dx.doi.org/10.1080/00222937408680917

$$
\text { 曲 Published online: } 13 \text { Oct } 2009 .
$$

Submit your article to this journal $\pi$

Џll Article views: 3

Q View related articles $\asymp$ 
A mphibia.

19. Bufo olivaceus.

$B$. affinis $B$. viridi $B$. vulgarique, ab ambobus glandulis parotoideis majoribus, valde latioribus, ovalibus, distinguendus; dorso subglabro; supra pallide olivaceus, subtus albescens.

Hab. in Gedrosia.

Four specimens taken.

Fuller descriptions and figures will be given in a forthcoming work on the natural history of Persia.

VII.-Description of a new Species of Skink. By A. W. E. O'Shaughnessy, Assistant in the Natural History Department of the British Museum.

Cophoscincus obscurus, sp. n.

Body tetragonal; tail thick, round. Internasal very large, covering the upper surface of the snout, concave posteriorly. Frontal narrow, triangular, rounded anteriorly; fronto-parietals separated; supraorbitals five, the fifth very small; frenal rather large, almost quadrangular, with the front upper angle pointed. Supralabials six ; infralabials four, narrow and long. Ear-opening none. Lower eyelid not transparent. Fiftytwo scales in a longitudinal dorsal series, fifty in a ventral one; twenty-two scales in a series round the body; those on the back larger. Number of scales between fore and hind limbs about thirty-four. Preanal scales larger. Limbs small, toes short.

Colour brown, with rows of black dots along the dorsal series of scales, and a dark streak from the eye along the upper lateral margin of the body to the tail.

This species evidently resembles closely the Lygosoma scutirostrum, Peters (Monatsber. Akad. Berl. 1873, p. 743), but differs in the number of scales between the fore and hind limbs, and in having no external ear.

Queensland. One specimen in the British Museum. 